\title{
Why I don't Blow the Whistle? Perceived Barriers by the University Teachers to Report Wrong Doings
}

\author{
Nargis Abbas ${ }^{* 1}$ and Uzma Ashiq ${ }^{2}$ \\ 1. Department of Education, University of Sargodha, Sargodha, Pakistan. \\ 2. Department of Social Work, University of Sargodha, Sargodha, Pakistan.
}

\begin{abstract}
Whistle blowing is a term used to report the unethical act of colleagues and wrongdoings within the organization. Bringing attention towards the misconducts and organization's effective response accordingly improves the productivity and quality of services. However, this generates the potential threats of organizational and interpersonal conflicts for the whistle-blower thus leads often failure in reporting by the personals or employees. This study explores the perceived barriers by the university teachers, which may hinder the process of reporting wrongdoings. Social constructionism qualitative research design is used. At first phase, face-to-face interviews of six faculty members and narrative research design has been used. At second phase, three focused group discussion sessions with total 24 participants, were carried out in three public sector universities of Punjab, purposively selected. Analysis shows that the people hesitate to blow the whistle due to psychological, social, and organizational barriers, like, fear of joblessness, security threats, lack of supportive organizational polices, lack of adequate mechanism for blowing the whistle, the personal waded interest of the personals. However, this procedure can be enhanced by addressing the issue well in time, adequate security measures, ensured job security for the whistle-blowers, and adoption of a well-developed reporting mechanism in the universities.
\end{abstract}

Keywords: Whistle Blowing, Organizational Barriers, Psychological Factors, Organizational Environment, Job threats, Reporting Mechanism.

\section{Introduction}

Whistle blowing, followed by immediate corrective actions, is a significant element to promote the organizational progress, and effectiveness particularly within the organization and in result, it increases societal trust (Bouville, 2008). On contrary, in the absence of such practices, public interests are harmed by the organizations when an organizational abuse occurs, such as, illegal practices, issues about moral values, and unethical behaviours (Gupta \& Chaudhary, 2017). Therefore, whistle blowing has gained contemplation world widely through print and electronic media, official reports, and whistle blowing polices (Bovens, 1998). A common definition of whistle blowing is of Near and Miceli (1994) that "the disclosure by organization members (former or current) of illegal, immoral, or illegitimate practices under the control of their employers, to persons or organizations that may be able to effect action" (p. 4). Whereas, the whistle-blower is the one who uncovers an unlawful act inside the organization or an illicit performance of powerful people. 
The term "Whistle-blowing" started in games, alluding to officials who whistled to stop illicit action or foul. Blowing a whistle by an official is very normal on playing fields or schoolyards. However, in 1970's, the term 'whistle-blowing' was embraced to separate charges from someone inside the organization rather than claims of an offense by somebody from outside the company (Edwards et al., 2009). Research revealed that when whistle blowing become a crime in an organizational context, whistle-blower is considered as disloyal (Pittroff, 2016). Hence, whistle blowing is likely to be dispirited and punished, consequently ethical silence occurs. However, it is an illusion to believe that wrongdoing can be avoided entirely while considering whistle blowing as an act of selfishness, disloyalty, disclosure of sensitive information (Rocha \& Kleiner, 2005). Therefore, the issue whether the employees should report wrong doings or not is still controversial due to the consequences in the form of costs and benefits. The one angle deals with the protection and security of the whistle-blower. Though protection of a whistle-blower often has taken in adverse essence as "rat protection" (Seligman, 1981, as cited in Miceli \& Near, 1992, p. 1). However, research also proves whistleblowers as protectors of society's interest as a whole (Finney, 1988, p. 40). Whistle-blower protection is a sensitive issue as whistle-blower reveals secret information; they deserve protection and should be rewarded as honest and honourable employees (Lindblom, 2007). Apart of this fact, it has been seen that whistle blowing has negative consequences on the individual who raises his voice against any wrongdoing. These consequences include pressure and stress such as; fear of retaliation/punishment, legal confrontation, and sometime, loss of resources and fire from job by the higher concerned authorities, and in severe cases, safety and life threats even after reporting (Putriana \& Prihatiningtias, 2018; Bjorkelo, 2013; Jackson, 2008; Hobfoll, 1989).

Therefore, whilst anticipating the consequences of the reporting any wrong doing and there upon being repentant/sufferer is a factor which stops or decreases the interest of employees to blow the whistle. Another angle deals with the decision making to report the wrong doing, that highly depends upon the main factors like, employee's individual, organizational, and social duties and responsibilities which may affect their decision making process (Apadore et al.,, 2018; Chen, 2018; Loyans, 2013: Jubb, 1999). In addition to it, psychological factors are those elements that add to the ways that a person thinks of his personality and thus effect on his decision-making power. These factors are self-esteem, organizational commitment, loyalty, emotions of fear, anger, anticipated regret, retaliation, etc. (Zeelenberg \& Pieters, 2007; Mesmer-Magnus \& Viswesvaran, 2005). Another vital factor has been identified by researchers which has significant association with whistle blowing process, that is, job satisfaction (Gupta \& Chaudhary, 2017; Cassematis \& Wortley, 2013). It is a feeling of fulfilment or enjoyment that worker attains from his job due to the supportive system within the organization. If a worker is satisfied with his job, he will have high sense of responsibility towards his organization and will thus report wrongdoings for the betterment of organization as compared to a person with low job satisfaction (Onder et al., 2019; Kuncara et al., 2017).

In addition, social factors are also found as the significant catalyst in whistle-blowing process (Taylor, 2018; Silva \& Sousab, 2017). These are the facts and experiences of individuals that influence their personality, attitude, and way of life. These factors include personal and demographic variables like age, gender, tenure of organization, job satisfaction, moral judgment, locus of control, level of job or length of service held, and ethical judgment, which have influence on reporting willingness (Gambrill, 2020; Fapohunda, 2016; Dungan et al., 2015; Friesdorf et al., 2015; Winardi, 2013). Organizational tenure or length of service influences the whistle blowing behaviour of employees. Senior employees are likely to own 
larger ability to report wrongdoing as compared to newly inducted employees as they are on the brink of retirement and have comparatively less worry of revenge (Taylor, 2018). Similarly, locus of control of the employees has a significant role in this process, which can be classified into inner or outer control. This control refers that an individual expects that he is responsible for the outcome of his behaviour or personal characteristics rather than claiming that the outcome is a function of chance, luck or fate (Ahmad et al., 2012; Chiu, 2003).

Furthermore, in this prudence, employee's behaviour, attitude, and workers' performance on exposure of misconducts is influenced by the organizational factors (Chen, 2018). These factors are organizational climate, organizational support, channel of communication and organization structure and its size. If organization provides ethical environment it will build the willingness of reporting in workers (Dalton \& Radtke, 2013). Therefore, certain organizational strategies are beneficial to support and encourage whistle-blowers (Wang et al., 2018). Thus whistle blowing manoeuvre the organizational culture to develop an ethical working environment, which helps to boost the employees' trust and permit them to detect and report the wrongdoings (Silva \& Sousab, 2017). For instance, these individuals may have greater commitment towards the pro-social organizational behaviour values and the belief that reporting of wrongdoings is good for the organization. Therefore, if organizational climate is supportive, whistle blower feels psychologically safe and less afraid of negative experiences. Moreover, the organizational support is also a key factor that influences the reporting intention. Many researchers confirmed that whistle blower would report when he believes that organization will take an action on his/her reporting and will support him/her. In addition, the whistle-blowing aspiration also depends on the accessibility of channel of communication within the organization. Without a proper communication channel, the management cannot work unbiasedly in dealing with the complaints. An effective whistle-blowing system is inescapable as in its absence, the overall reporting system becomes slow or ineffective (Near \& Miceli, 1995).

Most employees are acquainted with irregularities or misconducts within the organization but they cannot necessarily report them (Kaplan et al., 2010; Appelbaum et al., 2006). Thus, organizational error reports through the act of reporting wrong doings maintain the possibility of achieving a variety of positive results for the organization (Near et al., 2004). However, individuals who choose to detonate an unethical behaviour place themselves in a probably unsafe place. The situation is laden with personal and organizational penalty (Rehg et al., 2008). Many countries have developed policies and acts about workers protection that they can freely and safely report organization misconducts (Feldman \& Lobel, 2009). However, it is clear from previous research that there are differences in internal confidential reporting systems transversely at organizational or country level (Cuadrado et al., 2009; Hassink et al., 2007). The present government of Pakistan has launched recently a campaign for massive crackdown against the corruption by announcing a whistle-blower law against money launderers. However, in Pakistan, there is rare legislation on whistle-blower protection at federal as well as provincial level. Provincial government of Khyber Pakhtunkhwa legitimize the whistleblowing to promote the idea that it is beneficial for ethical culture and to improve government performance (Basri et al., 2017).

As far as concerning the types of wrongdoings, these also influence the intentions of the employees to report them (Stansbury \& Victor, 2009). An employee who observed serious kinds of offense, such as mismanagement, harassment, corruption, and legal devastation were more likely to inform than stealing, and injustice. Hassink et al. (2007) stated that whistle- 
blowing is an intentional non-mandatory disclosure, which is openly recorded and made by an individual with special access to information or association's data, about important anarchy or other bad behaviour, whether it is real, suspected or expected. Near and Miceli (2008) stated that whistle blowing is assumed as an injustice practices in an association, being propelled by the longing to counteract superfluous mischief to other people; raising worries about bad behaviour; giving data by and large to the experts about the bad behaviour; and presenting it to the press or stifling it in an administration office. The informant is a significant component in whistle blowing since the informant must be available all together for the whistle blowing to happen. Cambridge Dictionaries Online (2013) characterizes an informant as an individual who works for an organization or association that enlightens a specialist regarding something unlawful occurring inside the organization or association. However, Rothschild and Miethe (1999) described informants in two unique observations; some people view them as traitorous violators (dissatisfied or narrow-minded troublemakers) of organizational devotion standards and others consider them as brave safeguard of ethics (brave heroes).

Whistle blowing is grouped into two kinds: inward and outer (Miceli \& Near, 1992). Inner whistle blowing is characterized as the detailing of bad behaviour to an administrator or another person inside the association who can address the bad behaviour (Wortley et al., 2008). Caillier (2013) proposed that reporting to any of the accompanying channels like, colleagues, punctual administrators, abnormal state bosses, higher level organization authorities, the faculty office, and the Agency Inspector General, is viewed as interior whistle blowing. Employees who have confidence in the presence of powerful inner channels of complaint are bound to pursue inside whistle blowing. In addition, the non-appearance of sound inside revealing channels prevents people to report illegal or unethical acts in an association or to uncover their perceptions to anybody (Perks \& Smith, 2008). However, outer whistle blowing is referred as sharing bad behaviour to somebody outside the organization who might most likely stop or address it or have significant capacity to deal with the odd behaviour (Ahmad et al., 2012; Bashir et al., 2011). Mostly, outer informants first blow the whistle inside, however upon observing no actions against the complaint, they blow the whistle outside the organization (Gokce, 2013; Miceli \& Near, 2008; Rothschild \& Miethe, 1999).

Researchers viewed interior whistle blowing less dangerous than public securities resulting from outer whistle blowing (Ahmad et al., 2012). Hence, the decision of an inside or outer channel will provoke various outcomes; like, type of danger, benefits and response to the informant (whistle blower), the organization and the society. In addition, inner whistle blowing gives an organization the chance to find out about and fix its very own issues without the intercession of outside powers (Edwards et al., 2009). On contrary, Miceli and Near (1992) presenting the dark side of inside whistle blowing argued that it may involve the chance that the administration, rather than properly tending to the revealed bad behaviour, may wipe out proof of bad behaviour and hinder the informant from gathering solid proof of bad behaviour. Moreover, open divulgence of illegal or unethical actions occurring in the organization diminishes community trust, which is an incredible danger to the authenticity of any private organization (Lee \& Fargher, 2017; Miceli \& Near, 2015 \& 1985). Therefore, Vadera et al. (2009) rightly stated that even though both inner and outer whistle blowing have positives and negatives, however from an organizational outlook, outside whistle blowing is considered 'prone to hurt the organization'. Consequently, from an organization's outlook, inner whistle blowing is viewed better for the organization and consequently organization would lean toward that the informants utilize inward channels to report the bad behaviour as opposed to the outer (Near \& Miceli, 1996, p. 509). 
Organizational wrongdoings are very common and observable in current era. Illegal practices are increasing in the organizational context day by day even in Higher Educational Institutions (HEIs). The well-known types of wrongdoings that happen at HEIs are; breach of laws, illegal use of power and corruption in public funds, moral and ethical misconducts, biased assessment procedure; promotion on the base of wide unfurl nepotism; favouritism in the form of postings and rankings, negligence in investigation, literary theft, tempering of data and examination results, mushrooming of fake degrees and distributions (Choudhary \& Gupta, 2019 \& 2017; Schmidt, 2015). However, whistle blowing conducted by the faculty in HEls has not been investigated to an extent. The possible reason may be that university employees avoid reporting of such misconducts due to many psychological, social, and organizational factors. Thus, it becomes pertinent to investigate those factors that are creating barriers in the way of reporting. As Miceli et al. (2008) documented that the concerned defilement and wrongdoing in HEIs request powerful frameworks to oversee and report. There is a dearth of research work on employee's intention manipulating psychological, social, and organizational factors, which affect their decision of whistle blowing especially in HEIs in Pakistan. Therefore, why one does not blow the whistle? The answer for it can be explored by investigating their perceived barriers to report the wrongdoings.

This study explores how organizations and their workers go up against and handle illegal and moral wrong doings, which may include criminal activity, breach of any law, inappropriate or unauthorized use of public and other funds, injustice, the misuse of administrative powers. Moreover, it might provide an opportunity towards the development of some well-defined mechanism to investigate such acts in HEIs.

\section{Theoretical framework}

The current research paper is supported by General system theory (GST). GST provides a framework to study open system. This theory was vastly implemented in the behavioural and social sciences. In order to understand the functions and organizational structure, the GST provides a significant insight, as Bertalanffy (1968) depicted that a system does refer to a complicated and complex interaction among the different elements and their environment, which makes them self-regulatory. In addition, GST is helpful in resolving the issues of the complex and diverse organizations. Organizational complexities and diversities may include wrongdoings, illegal practices that have an influence on the organization. According to this theory, organization is a place where many employees work together. Every organization runs through a proper system that plays the role of backbone in organizing. The behaviour of an individual cannot be understood without reference to the system to which they belong.

\section{Research Methodology}

The study needed to provide the participants' perspective with detailed description of reporting wrongdoing phenomenon. Hence, a qualitative research methodology is adopted to explore the perceived barriers as the objectives of the study. According to the nature of the research study, narrative research design is used for the first phase of the study, that is, face-to-face interviews with six participants. This design is used because it is "a way of understanding experience" involving cooperation between researchers and participants over time, in a place or in a number of places, and in social interaction with the environment. Furthermore, narrative analysis or narrative inquiry is a qualitative research approach whereby the researcher analyses the stories 
people create, engaging in an inquiry of asking a given question of the narrative 'texts' for a given purpose. This approach can help us to understand how people are representing themselves, or their experiences, to themselves and to others. It comes under the umbrella of social constructionism. Therefore, to explore that why one does not report wrongdoing, the major themes were explored through six interviews through inductive coding under narrative research design.

In the second phase of the research, thematic analysis is adopted to deduce the sub themes. It still comes under social constructionism and it is a qualitative research approach, as thematic analysis lets us state the main topics or ideas that an interview or focus group transcript turns out to be about (Hennink, 2014). In order to achieve this purpose, three Focused Group Discussions (FGDs) were conducted. FGD method included an interactive discussion between eight preselected persons' group led by moderator to gain their wide range of views and perceptions on the particular topic or specific set of issues.

The population of this study is all public sector universities of Punjab, which are divided into three strata, North, Central and South Punjab. Therefore, one public sector general category university from each stratum is selected through simple random sampling. In the current research, for both interviews and FGDs, those participants are purposively selected who have either necessary knowledge or some experience of reporting wrongdoings by using purposive sampling technique. It is typical "to study a few individuals or a few cases" in qualitative research (Creswell, 2011) and in addition for each FGD, eight members are selected, in total 24 participant have participated in three FGDs.

Three public universities are selected as having more than ten years of age, which is a sufficient time to develop the mechanisms to facilitate the employees. Then preliminary themes are induced from six face-to-face interviews conducted with six faculty members of these selected universities (two faculty members are selected from each university). The time duration of each interview is 20 to 30 minutes. Narrative analysis of these interviews has been conducted.

\section{Narrative Analysis and Discussion}

Data collection for this research is done through interviews and focus group discussion to explore the teacher's perceptions regarding the barriers that affect their intention in reporting. Data collected from interviews are transcribed and themes are generated. In the first part, thematic analysis and its discussion are presented and in the next part, FGDs analysis is presented. The interviews are transcribed and thematically analyzed. In result, three major themes are generated as a barrier in the perception of the participants; these are, psychological, social, and organizational. These are found to be most influential barriers, which stop the whistle-blower to blow the whistle in HEIs. In the light of these major themes, sub themes are generated for focus group discussions. Thematic analysis is given below:

\subsection{Psychological Factors}

The first major theme that is generated is the psychological barriers along with the sub themes under this domain. The participants' interview results show that level of awareness of the whistle blower about the whistle blowing that when to blow, why to blow, how to blow, and where to blow matters a lot. Similarly, they talked about the importance of emotions of fear 
and anger as most of them are of the view that if they report there will be the worst situation for them. Due to this fear, they avoid reporting and in result, they may not undergo the feeling of regret. However, they are also of the view that if organization gives respect to the workers based on their performance it may boost their willingness to reporting wrongdoings due to increased self-esteem.

\subsection{Social Factors}

The second theme generated from these interviews transcriptions is the social factors. Interview data depicted that interpersonal, social relationships of the employees create hurdles in the way of reporting. Similarly, they also reported that cultural values and norms of the organization stop an individual from reporting several times. However, the interviewees also mentioned that observing and reporting the wrongdoing or misconduct is easier for the oldest employee of the organization and instead of a new employee. In replying for its reason, they are of the view that the older employees report more confidently due to their work experience and observations of the past such happening and its consequences. Moreover, due to more understanding of the environment of the organization, they know the tact to process the reporting of wrongdoings even in the absence of the reporting mechanism.

\subsection{Organizational Factors}

The last major theme that is explored in the transcriptions of the interviews is the organizational factor. They are of the perception that if an employee is loyal to his organization, he/she will report the wrongdoing within the organization. Secondly, interviewees commented that absence of organizational support might slow down the process of whistle blowing. They opined that the organizational environment is another factor, which do have an influence on the decisions of the employees to blow the whistle, or not. Similarly, they reported that in an organization the channels of reporting affect the whistle blowing process. In the light of the nine questions explored in the process of interviews' narrative analysis, three FGDs are undertaken in three sample universities. Eight faculty members participated in each FGD. Discussions are audio recorded and data is prepared for thematic analysis. Deductive thematic analysis of FGDs using hierarchal coding is as follows:

\subsubsection{Awareness about Whistle Blowing}

Most of the participants are of the view that whistle blowing is disclosure of something wrong, alarming, dangerous, and any act which is illegal and unlawful and for which a person blows his/her voice against that act in the organization to invite the attention of concerned authorities.

\subsubsection{Channels of Reporting}

Mental preparation about what is right and wrong before blowing the whistle is important and is the first step. Afterwards, employees' perception, that is, how to report and where to report (reporting through call or in black and white) plays a significant role because by doing so the records can be maintained to address the issues properly. In HEIs, the teachers are supposed to report the chairperson or higher authorities like Deans and Vice Chancellor. General discussion with the friends and colleagues is in practice verbally. In the case of serious issues like economic fraud and intellectual theft, they thought to report to chairman initially, however, if the problem is not solved, then reporting to the higher authorities in written form is best option 
using the proper channel if available.

\subsubsection{Experience of Blowing the Whistle}

The whistle blowing related to students' wrong doings is carried out frequently at the micro level. However, report against colleagues or an organization is ignored because it spoils relationships with others and may create some hazards for the whistle blower.

\subsubsection{Organizational Response and Environment}

When someone reports to a channel, it is organizational, situational, and social factors arise which creates obstacles in the way of a complete action. For instance, one teacher shared that "I saw a student cheating during exams and I reported it to the chairman. In the result of that reporting, that the student and his teachers did not talk to me for a long time. However, the student was punished so I found satisfactory results. Yes, I reported, but did not find more satisfactory results."

However, many teachers shared that, they complained several times, but did not find satisfactory results. They reported to the chairperson, but s/he even did not bother it. Instead of stopping that negativity, the immediate boss promotes it and becomes a part of it. Therefore, they did not find satisfactory results, however, if high authorities are supportive then a person likes to report and s/he does. There are a lot of wrongdoings for example, corruption, dishonesty, management issues teacher's biased behaviour, favouritism, discipline and behavioural issues, politics against colleagues, leg-pulling, jealousy, are common wrongdoings in the organizations, but teachers considered that their duty is just to teach. They have no time to notice the wrongdoing.

\subsubsection{Organizational Loyalty}

It is a general observation and perceptions of teachers about wrongdoings are not taken blissfully. The organization will support those things that are favourable to the organization. The organization will not support if the disclosure of misconduct will damage or spoil the reputation of the organization. It depends on case to case. There are many things like what the position reporter has in the organization? How influential his/her voice is? Communication skills also matter that how he reports wrongdoings. The organization will make an inquiry first. If the reporter gives evidence of misconduct and exposes his/her identity that $\mathrm{s} / \mathrm{he}$ is a person who witnesses that misconduct and s/he has proof of it then the organization can take an immediate step. Otherwise, if there is no proof there will be no action. If a person is reporting, it means that $\mathrm{s} / \mathrm{he}$ is loyal to his/her organization, but the organization will support if it is favourable for the organization. It also depends on the type of misconduct and ability to channel that how s/he handles this matter.

\subsubsection{The Reasons behind Non-Reporting Behaviour}

Generally, the teachers perceived that if they are victimized or affected by the reporting, then they would develop the thoughts like why we report. Alternatively, it is not needed to report. However, they also perceived that other reasons for non-reporting behaviours are lack of sense of responsibility for their duties and organization due to which they will not show any concern about reporting misconduct. Secondly, the response from authorities also affects the reporting 
behaviour. Thirdly, procedural difficulties affect the will of reporting. Long procedures discourage people from reporting. If employees believe that their voice will be listened, they will report more confidently. In their opinion, people ignore things because of the fear of being involved in procedural troubles. They will be punished so they remain silent to avoid conflicts with the colleagues. They think that it will ruin their reputation and image. Besides, fear of joblessness, blacklisting, bullying, the use of violence and abusive language against a reporter, transfer, fear of retaliation, fear of harassment are the reasons for non-reporting behaviour of the teachers. On the contrary, teachers did not report because they think that they can resolve the issue by themselves. Reporting may not be necessary for that purpose.

\subsubsection{Length of Service or Tenure}

New employees supposed to report more easily because they have more courage and energy for reporting. However, the reality is noticed that they ignore the things as their job is new and they did not want to lose it. Therefore, they have a resolution of not bearing the consequences. However, it is difficult for the employee with more length of service to report. The employees with more length of service becomes a part of an organization, they knew the rules \& regulations, difficulties after reporting, they have awareness about what will happen after reporting that's why they may ignore reporting. However, most of the time the practice of reporting is vice versa, i.e. employees with long job tenure reported the issues most confidently as they are on the edge of retirement, which reduces their fear of being victimized.

\subsubsection{Gender and Reporting}

All the teachers in FGD recognize the role gender. They are of the view that reporting of any wrongdoing is highly associated with the gender of the reporter, that is, females are found less responsive towards reporting any problem as compared to their male counterparts. By explaining the reason behind this phenomenon, for instance, one teacher stated, 'I can't say anything. Because genders do not matter, both males and females can report. Both genders can report but as you know in our society males are dominant, they report more confidently. Females avoid reporting because of the worst consequences like threats, harassment, joblessness, and family threats."

However, some of the teachers were of the view that if females have supportive environment they may report more confidently, because females are expressive, they cannot stop themselves from sharing or reporting. Similarly, they stated that the female has the more power to report because if she could not handle the problem by herself, she must go to the higher authorities to report. While, males can handle the situation by their self so if they even not go to the higher authorities, they can handle the situation and they did not take immediate action.

\subsubsection{Adoptable Changes in Organizational Environment}

The last important theme, as the suggested measure is the adaptable changes in the organizational environment. In this regard, teachers recommended various significant measures, these are; encourage workers to get awareness about the rules, and regulations regarding whistle blowing. Suggesting this, they are of the view that this is an organizational responsibility to give awareness to employees regarding their ethical responsibilities as a whistle-blower. Second suggestion is to minimize the procedural delays after blowing of a whistle because the delay in justice is injustice. Thirdly, provide easy access to the complainant 
for the reporting. Fourthly, minimize or reduce the fear of being victimized and fear of being bullied. Assurance of security measures is required that, if one will report s/he will not face any kind of social, psychological, or personal damage and information will be kept confidential. Communication channels should be effective and transparent. There should be prompt feedback and action. In addition, a committee or the council would be pertinent to deal with the misconduct within departments. There should be a proper communication channel to deal with misconducts in a supportive environment. Concerned authorities can provide freedom to report misconduct and safety to a reporter, which may consequently encourage them. Last but not the least, reward announcements for employees on the disclosure of serious kinds of wrongdoings within the organization is also suggested as the significant measure for enhancing the whistle-blowing procedure in the organization.

\section{Conclusion and Suggestions}

The thematic analysis of interviews and FGDs is found aligned with the existing literature as it is typical "to study a few individuals or a few cases" in qualitative research. In the light of results and discussion given above, it is found that most of the time, due to lack of awareness of the whistle blowing phenomenon, people misperceive it as an unethical act and disloyalty with the organization and thus avoid blowing the whistle. It is concluded further, that there are various perceived barriers due to which, teachers do not blow the whistle in higher education institutions. For instance, fear of losing job, security threats, fear of retaliation or punishment, organizational commitment, regret, and retribution are those psychological barriers, which prohibit an employee to report any wrongdoing in the organization. Moreover, social factors, like, gender, age, work experience of the complainant, cultural values, employees' interrelationships, ethical judgment, and locus of control serve as the hurdles thus affect the teacher's intention to blow the whistle. Similarly, the organizational factors like, lack of supportive organizational environment, lack of adequate mechanism for blowing the whistle, the personal waded interests, questions about the loyalty of the employee, organizational support, organizational structure, channel of communication are found as the perceived barriers in blowing the whistle. In order to create an ethical work environment within HEI where university employees would report wrongdoings without any barrier, university administration is assumed the responsible. Because if an employee thinks that $\mathrm{s} / \mathrm{he}$ is a worthwhile part of an organization s/he will have high self-esteem, which can later stimulate his/her anger and encourages individual behaviour to react against the wrongdoings or criminal actions and injustice practice.

Thus, keeping in view the findings of the current research, some valuable suggestions for the administration of the educational organization can be made in order to develop such an environment in which teachers will feel comfortable in all aspects to report every kind of wrongdoing in an HEI. The possible suggested measures are conducting trainings, refresher courses for the university faculty to render the awareness about the importance of the whistle blowing. Furthermore, provision of regular counselling sessions by appointing the human resource manager or social caseworker to deal specifically the psychological factors acting as barriers. In addition, whistle-blowing procedure can be enhanced by formulating internal committee or a special cell to address the issue well in time, adequate security measures, ensured job security for the whistle-blowers, and adoption of a well-developed reporting mechanism in the organizations. Future researches should be conducted to develop a particular mechanism of whistle blowing in the HEIs. 


\section{Acknowledgment}

We are grateful for the financial support of this work to the Higher Education Commission, Pakistan through NRPU Project 9393. Its contents are solely the responsibility of the authors and do not necessarily represent the official views of the HEC.

\section{References}

Ahmad, S., Smith, G. M., \& Ismail, Z. (2012). Internal whistle-blowing intentions: a study of demographic and individual factors. Journal of Modern Accounting and Auditing, 8(11), 1632-1645. https://ro.ecu.edu.au/ecuworks2012/638/

Apadore, K., Chin, C. Y., Qi, M. D. C., Yan, T. M., Yu-Sinn, W. G., \& Min, W. T. (2018). Factors affecting whistle blowing intention: an empirical study. South East Asia Journal of Contemporary Business, Economics and Law, 15(5), 104-114. https://seajbel.com/wp-content/uploads/2018/09/SEAJBEL15_233-1.pdf

Appelbaum, S., \& Shapiro, B. (2006). Diagnosis and remedies for deviant workplace behaviours. Journal of American Academy of Business, 9(2), 14-20.

Bashir, S., Khattak, H. R., Hanif, A., \& Chohan, S. N. (2011). Whistle-blowing in public sector organizations: evidence from Pakistan. The American Review of Public Administration, 41(3), 285-296. https://doi.org/10.1177/0275074010376818

Basri, S. A., Marsam, A. D., Nor, R. A. M., Abu, A., \& Mohamed, N. (2017). Reinforcement tool of whistle blowing to eradicate fraud in public sector. SHS Web of Conferences, 36, 1-6. https://doi.org/10.1051/shsconf/20173600038

Berry, B. (2004). Organizational culture: a framework and strategies for facilitating employee whistleblowing. Employee Responsibilities and Rights Journal, 16(1), 1-11. https://doi.org/10.1023/B:ERRJ.0000017516.40437.b1

Bjorkelo, B. (2013). Workplace bullying after whistleblowing: future research and implications. Journal of Managerial Psychology, 28(3), 306-323. https://phs.brage.unit.no/phsxmlui/bitstream/handle/11250/174696/workplace_bullying.pdf?sequence $=1$

Bouville, M. (2008). Whistle blowing and morality. Journal of Business Ethics, 81, 579-585. https://ssrn.com/abstract $=2739085$

Bovens, M. A. P. (1998). The quest for responsibility: accountability and citizenship in complex organisations / Mark Bovens. Cambridge University. https://www.loc.gov/catdir/toc/cam022/97010236.html

Caillier, G. J. (2013). Do employees feel comfortable blowing the whistle when their supervisors practice transformational leadership? International Journal of Public Administration, 36(14), 1020-1028. https://doi.org/ 10.1080/01900692.2013.798812

Callahan, E. S., \& Collins, J. W. (1992). Employee attitudes toward whistleblowing: management and public policy implications. Journal of Business Ethics, 11(12), 939948. https://doi.org/10.1007/BF00871960

Cassematis, P., \& Wortley, R. (2013). Prediction of whistleblowing or non-reporting observation: the role of personal and situational factors. Journal of Business Ethics, $117(3)$,

615-634. https://EconPapers.repec.org/RePEc:kap:jbuset:v:117:y:2013:i:3:p:615-634

Chaudhary, N. S., \& Gupta, K. P. (2019). A study of whistle-blowing intentions of teachers working in higher education sector. International Journal of Law and Management, 61(1), 106-132. https://doi.org/10.1108/IJLMA-10-2017-0253 
Chen, X. (2018). A summary of research on the influencing factors of employees' willingness to whistle blowing. American Journal of Industrial and Business Management, 8(7), 1732-1746. https://doi.org/10.4236/ajibm.2018.87116

Chiu, R. K. (2003). Ethical judgment and whistleblowing intention: examining the moderating role of locus of control. Journal of Business Ethics, 43(1), 65-74. https://doi.org/10.1023/A:1022911215204

Creswell, J. W., \& Plano Clark, V. L. (2011). Designing and conducting mixed methods research ( $2^{\text {nd }}$ ed.). Sage. https://doi.org/10.1023/A:1022911215204

Cuadrado, R., Alvarez Arce, J., Rodriguez-Tejedo, I., \& Salvatierra, S. (2009). Ethics hotlines in transnational companies: a comparative study. Journal of Business Ethics, 88, 199210. https://doi.org/10.1007/s10551-009-0110-4

Dalton, D., \& Radtke, R. R. (2013). The joint effects of Machiavellianism and ethical environment on whistle blowing. Journal of Business Ethics, 117(1), 153-172. https://doi.org/10.1007/s10551-012-1517-x

Donkin, M., Smith, R., \& Brown, A. J. (2008). How do officials report? internal and external whistle blowing. In A. J. Brown (Ed.), Whistleblowing in the Australian Public Sector (pp. 83-108). ANU. https://www.jstor.org/stable/j.ctt24h7w1.11

Dungan, J., Waytz, A., \& Young, L. (2015). The Psychology of whistleblowing. Current Opinion in Psychology, 6. 129-133. https://doi.org/10.1016/j.copsyc.2015.07.005

Edwards, M. S., Ashkanasy, N. M., \& Gardner, J. (2009). Deciding to speak up or to remain silent following observed wrongdoing: the role of discrete emotions and climate of silent. In J. Greenberg, M. S. Edwards, \& C. T. Brinsfield (Eds.), Voice and Silence in Organizations (pp. 83-110), Emerald.

Fapohunda, T. (2016). Gender: precursor of whistle blowing intentions and reprisals. International Journal of Research in Humanities and Social Studies, 3(12), 19-27.

Feldman, Y., \& Lobel, O. (2009). The incentives matrix: the comparative effectiveness of rewards, liabilities, duties and protections for reporting illegality. Texas Law Review, 88. 11-51. https://doi.org/10.2139/ssrn.1415663

Friesdorf, R., Conway, P., \& Gawronski, B. (2015). Gender differences in responses to moral dilemmas: a process dissociation analysis. Personality and Social Psychology Bulletin, 41(5), 696-713. https://doi.org/10.1177/0146167215575731

Gambrill, E. (2020). Avoidable ignorance and the politics and ethics of whistle blowing in mental health. Journal of Ethics in Mental Health, 11, 1-39. https://jemh.ca/issues/v9/documents/JEMH\%20article\%20WB\%20Gambrill\%20fin al.pdf

Gupta, K. P., \& Chaudhary, N. S. (2017). Prioritizing the factors influencing whistle blowing intentions of teachers in higher education institutes in India. Procedia Computer Science, 122, 25-32. https://doi.org/10.1016/j.procs.2017.11.337

Hassink, H., Vries, M. d., \& Bollen, L. (2007). A content analysis of whistle blowing policies of leading European companies. Journal of Business Ethics, 75(1), 25-44. https://doi.org/10.1007/s10551-006-9236-9

Hennink, M. M. (2014). Focus group discussions. Oxford University.

Hobfoll, S. E. (1989). Conservation of resources: a new attempt at conceptualizing stress. American Psychologist, 44(3), 513-524. https://doi.org/10.1037/0003-066X.44.3.513

Jackson, D. (2008). Editorial: what becomes of the whistle-blowers? Journal of Clinical Nursing, 17(10), 1261-1262. https://doi.org/10.1111/j.1365-2702.2008.02326.x

Jubb, P. B. (1999). Whistleblowing: a restrictive definition and interpretation. Journal of Business Ethics, 21(1), 77-94. https://doi.org/10.1023/A:1005922701763 
Kaplan, S., Pope, K. R., \& Samuels, J. A. (2010). The effect of social confrontation on individuals' intentions to internally report fraud. Behavioural Research in Accounting, 22(2), 51-67. https://doi.org/10.2308/bria.2010.22.2.51

Keenan, J. P. (2000). Blowing the whistle on less serious forms of fraud: a study of executives and managers. Employee Responsibilities and Rights Journal, 12(4), 199-217. https://doi.org/10.1023/A:1013015926299

Kuncara, A. W., Furqorina, R., \& Payamta, P. (2017). Determinants of internal whistleblowing intentions in public sector: evidence from Indonesia. In: $17^{\text {th }}$ Annual Conference of the Asian Academic Accounting Association (2016 Four A Conference), 20-22 November 2016, Kuching, Sarawak. http://doi.org/10.1051/shsconf/20173401002.

Lee, G., \& Fargher, N. (2017). The role of the audit committee in their oversight of whistle blowing. AUDITING: A Journal of Practice \& Theory, 37(1), 167-189. https://doi.org/10.2308/ajpt-51769

Lindblom, L. (2007). Dissolving the moral dilemma of whistleblowing. Journal of Business Ethics, 76(4), 413-426. https://doi.org/10.1007/s10551-006-9291-2

Loyens, K. (2013). Why police officers and labour inspectors (do not) blow the whistle: a grid group cultural theory perspective. Policing: An International Journal of Police $\begin{array}{llll}\text { Strategies } \quad \text { and } & \text { 27-50. }\end{array}$ https://doi.org/10.1108/13639511311302461

Mesmer-Magnus, J. R., \& Viswesvaran, C. (2005). Whistleblowing in organizations: an examination of correlates of whistleblowing intentions, actions, and retaliation. Journal of Business Ethics, 62(3), 277-297. https://doi.org/10.1007/s10551-0050849-1

Miceli, M. P., \& Near, J. P. (1992). Blowing the whistle: the organizational and legal implications for companies and employees issues in organization and management. Macmillan.

Near, J. P., \& Miceli, M. P. (2008). Wrongdoing, whistle blowing, and retaliation in the U.S. government: what have researchers learned from the Merit Systems Protection Board (MSPB) Survey results? Review of Public Personnel Administration, 28(3), 263-281. https://doi.org/10.1177/0734371x08319153

Near, J. P., Rehg, M. T., Scotter, J. R. V., \& Miceli, M. P. (2004). Do types of wrongdoings affect whistleblowing process? Journal of Business Ethics, 14(2), 219242. https://doi.org/10.5840/beq200414210

Near, J. P., \& Miceli, M. P. (1996). Whistle blowing: myth and reality. Journal of Management, 22(3), 507-526. https://doi.org/10.1177/014920639602200306

Near, J., \& Miceli, M. (1995). Effective whistle blowing. The Academy of Management Review, 20(3), 679-708. https://doi.org/10.2307/258791

Near, J. P., \& Miceli, M. P. (1985). Organizational dissidence: the case of whistle blowing. Journal of Business Ethics, 4(1), 1-16. https://doi.org/10.1007/BF00382668

Onder, M. E., Akçıl, U., \& Cemaloglu, N. (2019). The relationship between teachers' organizational commitment, job satisfaction, and whistle blowing. Sustainability, 11, 1-22. https://doi.org/10.3390/su11215995

Perks, S., \& Smith, E. E. (2008). Employee perceptions regarding whistle blowing in the workplace: a South African perspective. SA Journal of Human Resource Management, 6(2), 768-789. https://doi.org/ 10.4102/sajhrm.v6i2.159

Pittroff, E. (2016). Whistle-blowing regulation in different corporate governance systems: an analysis of the regulation approaches from the view of path dependence theory. Journal of Management \& Governance, 20(4), 703-727. 
https://doi.org/10.1007/s10997-015-9311-7

Putriana, A., Hariadi, B., \& Prihatiningtias, Y. W. (2018). Factors affecting intention on whistleblowing: an analysis on moderated model of whistleblowing channel. Journal of State Financial Accountability \& Accountability, 4(2), 125-145. https://doi.org.10.28986/jtaken.v4i2.218

Rehg, M., Miceli, M., Near, J., \& Van Scotter, J. (2008). Antecedents and outcomes of retaliation against whistle-blowers: gender differences and power relationships. Organization Science, 19, 221-240. https://doi.org/10.1287/orsc.1070.0310

Rocha, E., \& Kleiner, B, H. (2005). To blow or not to blow the whistle? that is the question. Management Research News, 28(11/12), 80-87. https://doi.org/10.1108/01409170510785264

Rothschild, J., \& Miethe, T. (1999). Whistle-blower disclosures and management retaliation: the battle to control information about organization corruption. Work and Occupations, 26, 107-128. https://doi.org/10.1177/0730888499026001006

Schmidt, W. (2015). Supply chain disruptions and the role of information asymmetry. Decision Sciences, 46(2), 465-475. https://doi.org/10.1111/deci.12133

Schultz, D., \& Harutyunyan, K. (2015). Combating corruption: the development of whistleblowing laws in the United States, Europe, and Armenia. International Comparative Jurisprudence, 1(2), 87-97. https://doi.org/10.1016/j.icj.2015.12.005

Silva, G. R. d., \& Sousab, R. G. d. (2017). The influence of the anonymous whistle blowing channel on accounting fraud detection in organizations. Journal of Accounting and Organizations, 30, 46-57.

Stansbury, J. M., \& Victor, B. (2009). Whistle blowing among young employees: a life-course perspective. Journal of Business Ethics, 85(3), 281-299. https://doi.org/10.1007/s10551-008-9770-8

Taylor, J. (2018). Internal whistle blowing in the public service: a matter of trust. Public Administration Review, 78(5), 717-726. https://doi.org/10.1111/puar.12946

Bertalanffy, L. V. (1968). General system theory: foundations, development, applications. George Braziller.

Vadera, A. K., Aguilera, R. V., \& Caza, B. B. (2009). Making sense of whistle-blowing's antecedents: learning from research on identity and ethics programs. Business Ethics Quarterly, 19(4), 553-586. https://doi.org/10.5840/beq200919432

Wang, T. K., Fu, K. J., \& Yang, K. (2018). Do good workplace relationships encourage employee whistle blowing? Public Performance \& Management Review, 41(4), 768789. https://doi.org/ 10.1080/15309576.2018.1464935

Winardi, D. R. (2013). The influence of individual and situational factors on lower-level civil servants' whistle blowing intention in Indonesia. Journal of Indonesian Economy and Business, 28(3), 361-376. https://doi.org/10.22146/jieb.6216.

Wortley, R., Cassematis, P., \& Donkin, M. (2008). Who blows the whistle, who doesn't and why? In A. J. Brown (Ed.), Whistleblowing in the Australian public sector: enhancing the theory and practice of internal witness management in public sector organizations (pp. 53-82). ANUE.

Zeelenberg, M., \& Pieters, R. (2007). A theory of regret regulation 1.0. Journal of Consumer Psychology, 17(1), 3-18. https://doi.org/10.1207/s15327663jep1701_3 